[This is the penultimate version of a paper forthcoming in Philosophy East and West. Please cite the published version.]

\title{
Iqbal's Fractured Vision: History as a Science and the Moral Weight of the Past
}

\author{
Sara Aronowitz \\ University Center for Human Values and Program in Cognitive Science, Princeton \\ University \\ skaron@umich.edu \\ Reza Hadisi \\ Philosophy Department and University Center for Human Values, Princeton University, \\ rhadisi@princeton.edu
}

\begin{abstract}
This paper aims to understand how we reason from historical premises to normative conclusions, tracing this question through the work of Muhammad Iqbal. On our reading, he wavers between two views of history, one a kind of natural science, and the other akin to religious interpretation. These tell different stories about the lessons we draw from history.
\end{abstract}

\section{INTRODUCTION}

If we look at the sources and foundations of modern ways of living, it becomes clear that the whole world is steeped in jāhilizyah [ignorance], and all the marvelous material comforts and high-level inventions do not diminish this ignorance.[...] It is now not in that simple and primitive form of the ancient jāhilīyah, but takes the form of claiming that the right to create values, to legislate rules of collective behaviour, and to choose any way of life rests with men, without regard to what Allah Almighty has prescribed. (Sayyid Qutb ${ }^{1}$ ) 
Sayyid Qutb (1906-1966), in this passage and others, condemns modern customs and society under the heading of jāhilīyah, or ignorance. This term, occurring several times in the Qur'ān, paradigmatically refers to the era in the Arabian peninsula which ended with the rise to power of Mohammad. By linking the modern period to this ancient one, Qutb communicated something particular about the moral problems of the society he lived in, as well as a call to action; just as we escaped from the ancient Age of Ignorance through religious revolution, so the new Age of Ignorance calls out for an almost literal re-birth of Islam. Here, situating the modern context in the past leads to a normative conclusion.

This pattern of inference is often psychologically compelling, and as a result, it is widespread in our everyday political and moral discourse. However, one might doubt whether this kind of inference is at all reasonable. One hesitation is that history itself seems to be a merely descriptive account of the past, and it is highly controversial whether descriptive facts can ever ground normative conclusions (notably, Hume denied the possibility of understanding such a grounding ${ }^{2}$ ). On the face of it, history is just descriptive. Descriptions on their own are normatively inert - so it seems that drawing a normative conclusion from a mere historical description requires additional normative premises.

Further, the jump from historical circumstance to moral imperative could be filled out in various ways. On the most innocuous reading, Qutb's inference is just an instance of analogical reasoning: our time is like the pre-Quranic times, revolution was then warranted, therefore revolution is now warranted. However, historical reasoning of this kind is also intended to convey moral propositions, rather than merely helping us discern where to apply the moral principles which we already grasp.

What makes Qutb's normative use of history especially peculiar is its aim to amend our views of the past as well as the present. To say that we are living in the Age of Ignorance is not like saying that our society is analogous to a person put in a situation of self-defense in 
a home invasion. When an interlocutor uses an analogy like that of self-defense, it would be unreasonable to respond by questioning the details of the hypothetical situation, since these details are merely stipulated. But in the case of history, the cogency of the argument does not rely on stipulation in the same way. It matters whether the Age of Ignorance really occurred as Qutb describes it, not just that it might have been so and that would have been dissolute. This difference is difficult to define; however, we hope the reader will find it intriguing enough as an initial example to be filled out later.

This paper is about historical reasoning to normative conclusions. This mode of reasoning is surely ubiquitous, but for several reasons, it takes on a particular character in the work of Qutb and other Islamic Revivalist thinkers of the mid-20th century. ${ }^{3}$ Consider a few examples. Tāhā Husayn, in a more optimistic mode, uses the successes of the Islamic Golden Age and Egyptian dynasties to form a blueprint for modern aspirations in Egypt. ${ }^{4}$ Abu'l Ala Maududi takes a similar line to Qutb, holding that the decline of Islamic culture can be traced all the way to the appointment of the fourth caliph, a decline that implicates a conception of statehood relevant to Islamic nationalism in his own time. ${ }^{5}$ Conversely, consider the pessimistic view of Jalāl Al-e Ahmad, who explicates the harmful and delusional relationship between Iran and the West by discussing the attitude of fetishistic nostalgia for a golden past in Gharbzadegi ["West-sickness" or "Occidentoisis"]. ${ }^{6}$

These Revivalist writers are grappling with three conceptions of history that are sometimes in competition with one another. First, many of these thinkers are well-versed in a Marxist (and by extension, Hegelian) conception of history as rule-governed and teleologically oriented. Ali Shariati, for instance, describes a Hegelian dialectic between the "Shi' ism of revolution" and the "Shi'ism of mourning", using the pattern leading up to modernity as a call to political action now. ${ }^{7}$ However, Shariati is also highly critical of the 
Marxist-Hegelian conception of history precisely because he thinks that it is not well-suited for grounding the desired normative conclusion and the call to action. ${ }^{8}$

Second, like many other thinkers of the (post-)colonized world, the Islamic Revivalists interact with history as means in the struggle against colonization. As a result, history already plays a major role as a political instrument. This is amplified by the fact that these thinkers were also influential public intellectuals.

Lastly, pre-modern Islamic thinkers, and the Qur'ān itself, had already accorded a certain pride of place to history in the study of human nature and ethics. Several Qur'ānic verses command Muslims to study history because it is a source of admoni tions, and thus moral knowledge. ${ }^{9}$ At least as early as al-Farābi, Islamic philosophers have theorized about history and its normative function. ${ }^{10}$ Ibn Rushd centers history in his analysis of social change in the commentary on the Republic. ${ }^{11}$ Most notable is, of course, Ibn Khaldūn's use of historical precedent to reveal laws of the rise and fall of civilizations in the Muqaddimah. "History", he writes, can give us "the useful result of being able to imitate historical examples in religious and worldly matter." ${ }^{12}$ In short, the tradition of making normative arguments from historical premises, and philosophical reflection on the normative import of history has deep roots in Islamic philosophy. Thus, in addition to the Marxist-Hegelian and the anti-colonial conceptions of history, the Islamic Revivalists also interact with this internal tradition.

Now, to make inroads in understanding this peculiar intellectual moment in the mid20th century, this paper focuses on a slightly earlier thinker who was deeply influential in Islamic Revivalism: Muhammad Iqbal (1877-1938). Iqbal impacted a new generation of thinkers in thinking about history. We see a hint of the place of history in a poem Iqbal wrote about the historic (and defunct) mosque in Cordoba. This' poem finds him meditating on the history of Islam and the West, culminating in the following lines: 


$$
\begin{aligned}
& \text { صورت شمشير به دستِ قضا ميل وه قوم كرتى به } \\
& \text { جوبر زمان اينه عمل كا حساب }
\end{aligned}
$$

Like a sword at the hand of fate (death/passed time), there is the community that all times gives an account of (keeps a record of/calculates) their actions ${ }^{13}$

History here is an essential, and perhaps violent, tool for survival in the de-colonial struggle.

At the same time, Iqbal tackled these questions of the meaning of history at an abstract, philosophical level, relating them to ongoing debates about Islam's place in science and politics. He further complicates this debate by operating with a conception of history as a science which is more modern than, for example, the Marxist-Hegelian conception. As we will see, it is a feature of Iqbal's general philosophy of science (and, consequently, his philosophy of history as a science) that he characterizes modern sciences as fragmented, modest in scope, and entangled with practices and objects. This conception of history as a science underscores our puzzle: how could history, as a fragmented, limited, and descriptive science at the same time be a source of normative insight as Iqbal - and other Islamic Revivalists - would have it?

Iqbal's central philosophical work, The Reconstruction of Religious Thought in Islam $(1930)^{14}$, lays out a program for Islamic philosophy in a modernizing world, demarcating the relationships between Islam, science, and history. The Reconstruction is by any measure the most significant work of Islamic philosophy written in English, and so this question is of historical interest for understanding Iqbal's view and its uptake in the subsequent Revivalist movement. Timur Kuran ${ }^{15}$ for instance, specifically links Maududi’s views on history to Iqbal, and much has been written on the complex relationship between the two thinkers. ${ }^{16}$ Shariati wrote a series of lectures and an essay on Iqbal (Mā va Iqbāal, "Iqbal and Us"), and Qutb penned an article on Iqbal's poetry. ${ }^{17}$ Rather than focus on any one of these specific connections, we will instead work out the nuances of Iqbal's view on its own 
terms - making progress on this interpretative question will in turn open up new ways of seeing Iqbal's legacy, which we sketch in the conclusion.

We start by elaborating the initial puzzle concerning the nature of historical-normative reasoning. In the subsequent sections, we present two threads in Iqbal's work, one about the relation between history and science, the second about the relation between history and religious interpretation. We argue that these two threads are in tension with one another, sketching two competing notions of history distinguished primarily by two distinctive, and incompatible, historical methods. Of these two methods - one scientific, the other interpretative - only the latter makes sense of historical-normative reasoning.

\section{THE QUESTION}

What is historical-normative reasoning? The basic pattern described above is one where a normative conclusion is drawn based on at least one historical premise, and where this reasoning goes beyond merely pinning a presupposed moral principle onto a new circumstance. The latter form of superficial historical-normative reasoning may be significant and interesting in its own right, but it reflects little about the nature of history since it is subsumed under a broader category of analogical reasoning. Call this pattern, which we'll attempt to exclude, simple moral analogy. Simple moral analogy is at work when, for example, we compare a withdrawal of military force to a child being abandoned. Here, it would be odd to respond to this argument by saying that the interlocutor has picked an unrepresentative example, since child abandonment tends to occur mostly by accident. This fact about the actual phenomenon is not relevant to the use of the stipulated phenomenon in the analogy because the actuality of the phenomenon is not essential to the analogy. In other words, one could make a similar moral analogy by suggesting that the withdrawal of military force would be like unicorns leaving baby unicorns in a dangerous 
situation. However, consider Qutb's analogy above; one might reply that the Age of Ignorance was in a large degree culturally continuous with the post-Quranic period. This reply does not seem irrelevant, nor could Qutb reply by saying, "that's beside the point, just treat the historical example as a stipulated hypothetical case!" But why not? We'll propose three distinct modes of historical-normative reasoning that explain why the actuality of the historical circumstance is essential to this family of arguments.

One step beyond simple moral analogy is bidirectional historical analogy. Here, drawing a moral connection between a contemporary circumstance and a historical one is used to sharpen our understanding of both circumstances. That is, in the simple case, the hypothetical example has moral features which are presupposed or already agreed upon; in bidirectional analogy, these moral features are only partially understood at the outset. For instance, I might think the Age of Ignorance society was morally bankrupt without knowing how or why. This explains why we are typically unwilling to brush aside questions about how well historical examples reflect historical fact.

This method of engagement is messy and abductive. Essentially, since neither side of the analogy is fixed, to come to a verdict means finding an equilibrium where both sides of the analogy fit. Camp ${ }^{18}$ distinguishes two ways to understand sentences like 'I am Anna Karenina', one where I use myself as a tool to understand Anna Karenina, and a second where I use Anna Karenina as a tool to understand myself (to simplify a bit). Likewise, understanding 'We're living in the Age of Ignorance' can be, in the case of simple analogy, using the Age of Ignorance as a tool to understand our moral situation, or in the case of bidirectional analogy, also using our situation as a tool to understand the Age of Ignorance. This latter strategy involves a balancing act between different possible ways of fitting things together. It remains a further question whether any particular equilibrium is the best equilibrium, assuming some uncertainty about the descriptive facts, the moral facts, or both. 
Bidirectional historical analogy cannot be reduced to a hypothetical form because the reasoner will typically be in the process of figuring out which features of both situations are morally significant, and why. But how can this reasoning generate moral knowledge? Bidirectional analogy is consistency reasoning. So if moral propositions are part of what is being negotiated, they are candidates for revision and emendation. Consequently, a reasoner could come to know a new moral principle through such reasoning. To be sure, consistency in moral thinking does not guarantee moral knowledge, but short of luck or magic, it is one of our best means for discovering moral principles. By contrast, through simple analogy, a reasoner could only come to learn that a principle which she already knew applies to a new case.

Historical genealogy goes beyond simple analogy in a different direction. Here, we reject reducing the historical case to a hypothetical because the argument works by invoking a connection between the past and the present that does not hold between the hypothetical past and the present. This is a genealogical relation. The past takes on its significance not because of its intrinsic properties (for instance, the psychological complexity of a historical agent might make her an especially interesting example), but because it is our past. Brought to prominence by Nietzsche, the genealogy relation can take either a metaphysical or epistemological form. In the former case, we need to understand our moral views through their history because they are constituted by their history; our apparent concept of courage, for instance, is only the tip of the iceberg of a complex concept that includes how we have evolved in our use of terms designating courage over time. Alternately, our history might be important because it serves a unique epistemic role. On this view, understanding the history of morality is essential because it is a window into understanding the present by understanding how it came to be. In either case, historical genealogy allows for moral learning because historical understanding is a privileged 
position from which we can see contemporary practices, including normative beliefs, more clearly.

The third kind of historical-normative reasoning is historical generalization. Here, we assume history is a source of information about some moral (or morally relevant) propositions. Perhaps studying history allows us to grasp human nature, or the nature of autonomy, or on a grander scale, the principles which govern changes to social and political circumstances. Views on which history has a direction lend themselves naturally to historical generalization ${ }^{19}$, as do views on which history is a kind of science of human nature wherein we aim to understand unchanging principles or laws. Historical generalization denies the move to the hypothetical because only actual human history can normally be a database for generalization, just like only actual plants can normally support biological inferences. We say 'normally' because hypothetical premises do play a role in historical and scientific generalization, but not as a replacement for actual data. Normative inferences can come from historical generalization in two ways: (1) we might learn where to apply conditional moral premises (e.g. 'if human nature necessarily leads to some action, then that action is morally permissible'), or (2) the propositions we extract from the historical data may themselves be moral (e.g., 'humans are genuinely autonomous').

These three kinds of historical-normative reasoning have distinct applications and limitations, though they are sometimes employed together. The applicability of each method depends on controversial presuppositions, chiefly concerning the nature of historical study and our relation to it. After extracting Iqbal's views of history, we will return to this taxonomy to determine which methods Iqbal's theory of history supports. 


\section{TWO CONCEPTIONS OF HISTORY}

This section brings out two approaches to history presented in the Reconstruction.

Ostensibly, Iqbal discusses a single notion of history throughout the book. However, we aim to show that below the surface, there are two incompatible conceptions invoked at different times and performing different functions. This text is centered around religious experience, making the case for a complex role for religious experience as a genuine medium of knowledge as well as a capacity implicated in other intellectual and practical activities. As such, a natural way to understand history in this text is to understand how it relates to religious experience.

\subsection{HISTORY AS A SCIENCE}

Throughout the Reconstruction, Iqbal talks about history "as a science." For instance, he notes that Ibn Khaldūn "laid the foundations for modern scientific history." ${ }^{20}$ At another point, he argues that the Qur'ānic treatment of history lays down the necessary conditions for the "possibility of a scientific treatment of history." ${ }^{21}$ Even more importantly for our purposes, after defending the status of religious experience as a source of knowledge in the first half of the Reconstruction, he turns his attention "outward" and groups the study of history with the study of nature as among the sources of knowledge:

[I]nner experience is only one source of human knowledge. According to the Qur'ān , there are two other sources of knowledge- Nature and History; and it $^{-}$is in tapping these sources of knowledge that the spirit of Islam is seen at its best. ${ }^{22}$

Notably, the passage continues in a manner that shows that, for Iqbal, the affinity between the study of nature and history is methodological:

The Qur'ān sees signs of the Ultimate Reality in the "sun", the "moon", "the lengthening out of shadows", "the alternation of day and night", "the variety of 
human colour and tongues", "the alternation of the days of success and reverse among peoples" - in fact in the whole of Nature as revealed to the sense-perception of $\operatorname{man}^{23}$

Here, Iqbal is grouping the study of "sun" and "moon" (natural sciences) with the study of "the alternation of the days of success and reverse among peoples" (history). Crucially, he justifies this grouping by appeal to the method by which these enquiries approach the world: they are both empirical, that is, "revealed to the sense-perception". Unlike a view on which history involves rational meditation on first principles, for instance, Iqbal invokes sense perception here to relate history to the natural sciences under a common form of understanding.

So the first view that surfaces in the text is that history is a science, relevantly similar to the natural sciences. Iqbal was heavily influenced by Hegel $^{24}$, and history as a science might be reminiscent of a Hegelian conception under which (philosophic) history aims to reveal the "rational necessary course of the World Spirit." ${ }^{25}$ However, Iqbal was appealing to a more modern and less rationalistic conception of science on which science is a messy process of finding things out about the world that is significantly affected by social position and context. For instance, as we saw a moment ago, on Iqbal's account, the study of nature and history share the feature that they are both "revealed to the sense-perception of man." At least on the face of it, this kind of radically empirical methodology does not fit well with the Hegelian conception of history as involving an analysis of the necessary laws of the "Spirit". So, it would be a mistake to overstate the influence of the Hegelian conception of "the science of history," and read that into Iqbal's account of history as a science. ${ }^{26}$

Hence, as we have suggested, to understand Iqbal's first conception of history as a science, we must look more carefully at his conception of the sciences more generally. The principal aim of Iqbal's discussion of science, made explicit in Chapter 1 of the 
Reconstruction, is to understand the relationship between science and Islam. In fact, Fazlur Rahman treats this as the central contribution of the book. ${ }^{27}$ The conclusion Iqbal reaches is that Islam and science are indeed compatible, even though there might be some prima facie conflict. The following passage contains the core of the argument:

There is no doubt that the theories of science constitute trustworthy knowledge. But we must not forget that what is called science is not a single systematic view of Reality. It is a mass of sectional views of Reality - fragments of a total experience which do not fit together. Natural Science deals with matter, with life, and with mind; but the moment you ask the question how matter, life, and mind are mutually related, you begin to see the sectional character of the various sciences that deal with them, and the inability of these sciences, taken singly, to furnish a complete answer to your question. In fact, the various natural sciences are like so many vultures falling on the dead body of Nature, and each running away with a piece of its flesh. [...]. The moment you put the subject of science in the total of human experience it begins to disclose a different character. Thus religion, which demands the whole of reality and for this reason must occupy a central place in any synthesis of all the data of human experience, has no reason to be afraid of any sectional views of Reality. ${ }^{28}$

The central argument of the passage is this: were science and religion both fragmentary in their approach to reality or both holistic, then they would be in competition. But the sciences approach reality in a way that is "fragmentary" or "sectional". Religion approaches reality in a holistic manner, "synthesizing" the fragments that other sources of knowledge provide. Therefore, Iqbal sees no conflict between religion and science. Note that this analysis of the argument takes the crucial difference between science and religion to be in methods rather than goals - an issue we return to in Section 4. 
One difficulty with this argument is an ambiguity about the conclusion. Even Iqbal's own example here suggests that there might be a conflict between religion and science. The vultures feeding on the body are presumably in competition with something which demands the whole of the body - i.e. its organic unity or its "life". That is, if the two approaches - the fragmentary vs. the holistic- are about one and the same reality, then they could be in conflict. That is so because often methodology presumes metaphysics. If two different methodologies presume two incompatible kinds of reality, then we cannot assign both methods to the task of studying the same reality. For example, it is often assumed that pure a priori reasoning is an appropriate methodology only for necessary truths. So, were we to suggest that we can study the evolution of whales via purely a priori methods, we would be committing to claims about the nature of evolutionary facts, namely that they contain necessary truths. And if so, then one could worry that empirical observations are not the best method for studying evolution because they are usually inapt for getting us to necessary truths. Likewise, to suggest that reality can be studied holistically seems to entail certain commitments about the nature of reality - for one thing, it entails that reality in itself is a unified whole. If so, it looks as if science cannot grasp reality at all. Indeed, in Chapter 4, Iqbal seems to says as much: It seems that the method of dealing with Reality by means of concepts is not at all a serious way of dealing with it. Science does not care whether its electron is a real entity or not. It may be a mere symbol, a mere convention. Religion, which is essentially a mode of actual living, is the only serious way of handling Reality. ${ }^{29}$ But recall Iqbal's claim from the earlier passage that the sciences do "constitute trustworthy knowledge." So how could the sciences constitute trustworthy knowledge and at the same time not constitute a serious way of dealing with Reality?

Iqbal offers a resolution to this apparent tension by invoking the idea of "degrees of reality." He attributes the idea to Shahab al-Din Suhrawardi (1154-1191), and praises Hegel 
for offering a modern version of the view. ${ }^{30}$ According to Iqbal, whereas religion is suited to study the highest degree of reality (which he labels "Reality" in the text), scientific concepts are "sectional in character, and their application is relative to the level of experience to which they are applied." ${ }^{31}$ Iqbal uses examples from the practice of modern science as well as self-reports of practicing scientists to establish this claim. One of his favorite examples comes from J. S. Haldane's 1918 paper, “Are Physical, Biological and Psychological Categories Irreducible?"32 In that paper, Haldane argues that physics' concepts of mechanism and the mechanical conception of cause are not fit to describe phenomena like living organisms and reproduction at the level of biological reality. Iqbal notes:

No doubt, there are aspects of the activity of a living organism which it shares with other objects of Nature. In the observation of these aspects the concepts of Physics and Chemistry would be needed; but the behaviour of the organism is essentially a matter of inheritance and incapable of sufficient explanation in terms of molecular Physics. ${ }^{33}$

We hope that Iqbal's general theory of science is now emerging. On his account, natural sciences study reality by carving up a section or a layer of reality-as-a-whole. He summarizes this view nicely when he writes:

Natural Science is by nature sectional; it cannot, if it is true to its own nature and function, set up its theory as a complete view of Reality. The concepts we use in the organization of knowledge are, therefore, sectional in character, and their application is relative to the level of experience to which they are applied. 
Notably then, for Iqbal, the fragmentary nature of science concerns both the content and the method. The "subject-matter" of sciences are fragmentary because they are by nature not interested in "a complete view of Reality" - scientific concepts isolate phenomena "to the exclusion" of other aspects of reality. More importantly for present purposes, Iqbal seems to imply that the fragmentary nature of sciences is a result of their segmented methodology.

What could a segmented methodology be? One element is likely asking small-sized questions. The sciences use methods that are, in Iqbal's analogy of vultures, well-suited to 'dead' subjects. For instance, he might mean laboratory methods that take a piece of a biological system out of its context and into a controlled environment. Alternately, in the recurring example of Physics, the methodology of reduction to a stark idealization might count as segmented. By distilling a system to a few idealized components, we could be metaphorically taking a small bite of reality. In either case, the method of science entails ignoring or removing information, as a feature of the method rather than a shortcoming or hidden flaw. As Iqbal puts it, "Nature as the subject of science is a highly artificial affair, and this artificiality is the result of that selective process to which science must subject her in the interests of precision." 34

Now that we have some characterization of what it means to be a science in Iqbal's sense, we need to determine what history is a science of. Just like the natural sciences, history is "by nature sectional." Historical concepts and historical knowledge are like natural concepts and knowledge in that their application is only "relative to the level of experience to which they are applied" and they study phenomena "to the exclusion of other forms of activity." Accordingly, we need to ask, which fragments of reality are studied by the science of history.

We find an initial answer in Iqbal's Romuz-e Bikhodi [The Secrets of Selflessness], where he connects history to Biology and Economics: 
While in the case of individuals the thread of continuity in the life of the self is furnished by memory, in the case of nations this continuity and consequent stability is provided by the safeguarding of national history....I have tried to review the synthesis of the Islamic community and its various components and elements from this biological and economic standpoint. I am convinced that a proper understanding of the life of the Muslim community of nations can be obtained only when we approach the problem from this angle. ${ }^{35}$

This passage indicates two relevant points: first, when Iqbal thinks of history as a science, he means it not in the general sense of Wissenschaft, which would include the humanities, but in the more specific, ordinary English sense. Second, we see a suggestion that the object of history be the evolution of a community over time, and the forces which bind such a community together.

The traditional candidates for the object of history include human nature, human society and the development of human society. And in the Reconstruction, Iqbal seems to suggest that history is a science of human social development, consistent with the passage above. This becomes apparent when he praises Ibn Khaldūn for viewing "history as a continuous, collective movement, a real inevitable development in time. ${ }^{36}$ On the face of it then, history is a descriptive science about how societies change.

However, Iqbal's account becomes complicated when we note his interpretation of Ibn Khaldūn's conception of history as a continuous development in time:

The point of interest in this view of history is the way in which Ibn Khaldūn conceives the process of change. His conception is of infinite importance because of the implication that history, as a continuous movement in time, is a genuinely creative movement and not a movement whose path is already determined. ${ }^{37}$ 
So, although Iqbal thinks that history is a study of societal change and development, it is importantly a "creative" and not predetermined change and development that is at stake here. Hence, we can start to see the beginning of a connection between a descriptive science and a normative discipline in Iqbal's thought. Indeed, this connection is underscored by Iqbal himself. An entry in his diary reads as follows:

History is a sort of applied ethics. If ethics is to be an experimental science like other sciences, it must be based on the revelations of human experience. ${ }^{38}$

Here, it sounds like our subject matter is directly ethical. And at the same time, note that Iqbal still insists on the affinity of history and "experimental sciences." To be sure, these notebooks are somewhat aphoristic, and probably don't entirely reflect Iqbal's considered views in the Reconstruction. In the Reconstruction, we are presented with a somewhat enigmatic conception of history as a theory of "creative" and not predetermined social development. In the notebook, we can see hints of the kind of theory which Iqbal hopes to develop: one that can account for history both as an experimental science and a source of normative insight. Later, we will question whether Iqbal can deliver on this promise. But first, we need to look at a second conception of history which also appears in the

\section{Reconstruction.}

\subsection{HISTORY AS INTERPRETATION}

As we've seen, Iqbal frequently refers to history as a science, both in the Reconstruction and in his notebooks. But another face of history presents itself later in the book, where history has a special place in Islam's religious worldview, at odds with the non-competing, fragmentary approach detailed above. The first inklings of this shift are at the very beginning of Lecture $\mathrm{V}$ of the Reconstruction. The central problem that Iqbal tackles in this lecture is to understand 'the soul' of the Prophet Mohammad, especially because he thinks 
that the Prophet's interpretation of religious experience is unique and highly valuable. He introduces the topic by citing the Indian Sufi thinker, Abd al-Quddus of Gangoh (14561537) who is reported to have said that the Prophet "ascended the highest Heaven and returned. I swear by God that if I had reached that point, I should never have returned." 39 Iqbal takes Gangoh to be pointing to a difference between the prophetic attitude towards religious experience and an ordinary mystic attitude. Whereas the mystic can interpret his or her religious experience only in seclusion from society, Gangoh sees the prophet as capable of having the highest kind of religious experience while living a fully socialpolitical life. Accordingly, Iqbal puts forth the task of understanding the Prophet's "soul" because "religious experience transformed into a living world-force is supreme in the prophet." ${ }^{40}$ In short, for Iqbal, the task is to understand the religious world-view in its "highest" exemplification by the Prophet.

But surprisingly, he turns to exploring the Prophet's 'soul' through the history of Islamic culture:

I want rather to fix your gaze on some of the ruling concepts of the culture of Islam in order to gain an insight into the process of ideation that underlies them, and thus to catch a glimpse of the soul that found expression through them. ${ }^{41}$

These 'ruling concepts' are elements of intellectual history; for example, the following passages discuss the interaction between the entrance of Greek philosophy into the Islamic world and the doctrine that Mohammad brings about the finality of the institution of prophethood. Iqbal makes the bold claim that we can understand "the value of [the] prophet's religious experience" if we understand this historical transition. ${ }^{42}$

This description of history, as a vehicle for understanding the soul of the prophet strikes a contrast with the scientific conception that we encountered in Section 3.1. Here, history is 
a study that reveals a central religious premise, namely the meaning of the Prophet's religious life and experience. Thus, history is now being used to offer a central religious insight, or more precisely, the religious ideal model (in the Prophet Mohammad) which Muslims ought to follow. Both the centrality of this exemplar and its religiosity are at odds with the scientific nature of history; the former is in tension with the fragmentary nature of science, and the latter, with the separation of science and religion into fundamentally different perspectives.

But what would it mean to look for the soul of the Prophet in history? An even more striking passage follows a few pages later:

History or, in the language of the Qur'ān, 'the days of God', is the third source of human knowledge according to the Qur'ān. It is one of the most essential teachings of the Qur'ān that nations are collectively judged, and suffer for their misdeeds here and now. In order to establish this proposition, the Qur'ān constantly cites historical instances, and urges upon the reader to reflect on the past and present experience of mankind. ${ }^{43}$

Here, again, interpreting history is a way to reflect on religion, in this case including religious morality. Note the interpretive language; the reader is meant to reflect on the past, as opposed to pursuing historical data, just as in the previous passage, the aim was to fix your gaze on the historical material. Of course, gathering data is compatible with reflecting or fixing one's gaze. But the language here suggests historical inquiry as primarily about contemplation and personal experience. To make the contrast more obvious, think how peculiar it would be to characterize Physics or Biology as ways of reflecting or fixing one's gaze. 
Both the connection with religion, and the language of contemplation suggests a similarity between this reflection on history and the interpretation of religious texts and sources. Reading and reflecting on the Qur'ān, for instance, could take up the same subject as the study of history in this lecture: revealing the character of the Prophet and moral knowledge about how mankind will be judged. That is, we see both a similarity in content and method between history and religious interpretation. History, on this view, is a way of studying human affairs to bring out their meaning, not in a limited and fragmentary manner, but in a manner that would reveal Reality as it was seen through the soul of the Prophet i.e., in its entirety.

Compare the method of science to the method of interpretation. Science, as described in the previous section, takes a piece of reality out of its full context, either through idealization or experimentation. Interpretation, conversely, often involves looking at a small episode through its context. For instance, interpreting the Qur'ān might involve thinking about how a story about the Prophet Harun (Aaron) connects to the concept of responsibility. This story can be seen as a miniature version of the entirety of religious teachings, rather than one data point in assembling a generalization. Seeing the whole in a small part is common enough in legal and literary interpretative practices, but in the Islamic religious interpretative traditions, it is particularly pronounced. ${ }^{44}$

Interpretation is usually holistic but is also more passive than science. Recall that the scientific practice of pulling out a segment of reality "is a highly artificial affair, and this artificiality is the result of that selective process" that characterizes the scientific method. ${ }^{45}$ This artificial construction of fragmented laboratorial reality has no counterpart in religious interpretation. This even applies when interpretation focuses on a tiny example without much mind to the connections between that example and other parts of the text. Fixing one's gaze on the example is different than pulling out a phenomenon for an experiment, or 
idealizing away from details to see the structure. In the religious interpretive case, the connections to the overall worldview, even if not part of the focus, must be part of the endeavor, at least in principle - otherwise the interpretation could not be held up against the spirit of the text as a whole. By contrast, in the case of science, the context must be hidden or made remote - for Iqbal, a scientific account, "cannot, if it is true to its own nature and function, set up its theory as a complete view of Reality." 46

Now, on the one hand, we hope it is clear that this second conception of history as religious interpretation is at least prima facie in conflict with the conception of history as science that we explored in Section 3.1. On the other hand, it is also easier to see how history as religious interpretation could have normative import. After all, the central purpose of religious interpretation is to understand how a religious life should be lived. In Iqbal's case, as we saw, this is the main theme of Lecture V of the Reconstruction- he seeks to understand how a religious experience could be "transformed into a living world-force" as the example of the Prophet shows. And he tries to account for Mohammad's example through historical analysis. But can the two conceptions of history be made compatible?

\section{RECONCILING THE TwO CONCEPTS}

In Section 3.1., we already saw how Iqbal tries to reconcile science and religion. He argues that it is possible for the two incompatible projects to exist side-by-side, pursuing their own separate ends. For instance, in his Koliyat, we read:

The Science of Names is what gives Man worth

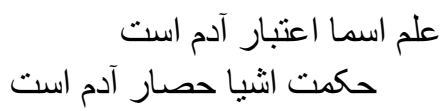

The Wisdom of Objects is man's fortification ${ }^{47}$ 
These lines contain a peculiar twist - hikma (wisdom) is more naturally associated with the non-fragmentary holistic viewpoint of religion, whereas 'ilm (science) is often used to refer to specific sciences. More importantly, here, Iqbal distinguishes between religion and science by distinguishing between their ends. Whereas the end of worldly wisdom - i.e., knowledge provided by sciences - is to provide instruments or a shield for humanity, the end of religious sciences ("the Science of Names" ${ }^{48}$ ) is to direct us towards the intrinsic worth of humanity. In this way, science and religion are made compatible in virtue of very different ends, and subsequently, domains.

So, one may wonder if the same model could apply to the relationship between history as science and history as interpretation. One might argue that history can be employed for two different ends: first, in service of providing necessary instruments for humanity, and second, in service of the inner worth of humanity. In the first case, history is a science. In the second case, history is a mode of religious interpretation.

Against this, we argue that Iqbal's model of the compatibility of religion and science cannot be applied to account for the compatibility of the two conceptions of history in a meaningful way. This is because of an equivocation over "compatibility". Science and religion, for Iqbal, should be compatible in the sense of not competing with one another. Two kinds of history, on the other hand, should be compatible in the sense of joining together to form two parts of a single inquiry - if they can rightly be both called history, at least. We'll call this first kind of compatibility noncompetition, and the second coherence. At least on the face of it, these two histories are the same inquiry - or at a minimum, two faces of the same inquiry. Two fields that differ in terms of method in the way the two histories do could in principle coexist - but history could not be so split while remaining in even the weakest sense a single field. 
The incoherence of history as science and history as interpretation could be understood in terms of either subject matter or method. Though, since subject matter constrains method and vice-versa, the end result may be an incoherence of both subject matter and method. We will suggest that Iqbal's two terms are best separated by method, with subsequent differences in subject matter following from prior differences in method.

The case for an incoherence in subject matter might initially seem promising. When we were looking at Iqbal's conception of history as religious interpretation, we noted that he takes the object of the inquiry to be the 'days of God'. ${ }^{49}$ But the language of the 'days of God' invokes a more grandiose object of study than what we encounter in the historical science. And this distinction is not unprecedented. Hegel distinguishes between 'world history' and 'universal history'. The former concerns the intellectual development of human society as a whole, and the latter particular societies and nations. And world history employs a distinctive methodology in part because of this difference in subject-matter. For Hegel, world history and universal history are two distinct intellectual inquiries, and incompatible as conceptions of a single inquiry. ${ }^{50}$ Or as a more extreme contrast, Isaiah Berlin describes Tolstoy as making a distinction in subject matter between Hegelian world history and "the ultimate data of subjective experience - the personal lives lived by men, the thoughts, knowledge, poetry, music, love, friendship, hates, passions of which, for Tolstoy, 'real life' is compounded, and only that.",

On the other hand, there is little evidence in the text that Iqbal is discussing distinct subject matters when switching between presenting history as a science and as interpretation. Presumably a difference in subject-matter would be fairly easy to identify and yet the discussion of history in the Reconstruction is almost exclusively an analysis of intellectual histories localized to either a region or specific time period, or both. 
An incoherence in method, however, is inherent in the very notions of religious interpretation and science. One method dictates holism, the other atomism. One is a search for meaning, the other an analysis of causal forces. Textually, Iqbal is already committed to the incompatibility of holism and atomism in a single inquiry since it underlies the argument about religion and science with the metaphorical vultures. That argument was intended to show that religion and science do not compete with one another, but a consequence of saying that two methods cannot compete with one another (even, subtextually, when they appear to be at odds) is that they cannot be one and the same inquiry.

Dwelling on the example of the vultures suggests a further claim. The scientific vultures are in fact feeding off of the same body that religion also tries to grasp. But by the time they consume it, the body is dead and broken apart, irreversibly changed. By analogy, while the two kinds of history share a subject matter, Iqbal's analogy suggests that these deep differences in method might lead to the same subject matter being presented in unrecognizable guises. As we saw earlier, Iqbal thinks that whatever the difference in subject matters of science and religion might be is "the result of" having different methods. $^{52}$

This takes us to the very heart of the problem, and promise, of this text. Iqbal himself does not acknowledge the tension we are describing in the case of history, and often the two senses appear deeply entangled. In Lecture V (which, recall, contains the discussion of history as a source of religious knowledge, illuminating "the prophet's soul") refers directly to history as a science:

However, the interest of the Qur'ān in history, regarded as a source of human knowledge, extends farther than mere indications of historical generalizations. It has given us one of the most fundamental principles of historical criticism: Since 
accuracy in recording facts which constitute the material of history is an indispensable condition of history as a science, and an accurate knowledge of facts ultimately depends on those who report them, the very first principle of historical criticism is that the reporter's personal character is an important factor in judging his testimony. $^{53}$

Here Iqbal claims that Islam gives us not just historical knowledge but historical principles: in this case, the principle that assessing the validity of testimony involves assessing the character of the testifier. Are these scientific principles? On first glance, the way a person's testimony is assessed through, for instance, the laws of transmission of Hadith, and through a scientific assessment of a historical period look alike: both are interested in accuracy, and so both might ascribe to the principle above. But looking more closely, Iqbal picks out a principle about the 'personal character' of the testifier. In the transmission of Hadith, personal character is of direct concern. But would a historian studying the development of astronomical tools be interested in the personal character of an author of a text? Perhaps incidentally, but not as a route through which to weigh the text itself; after all, historians are more often interested in what texts reveal about their times and authors than as clear windows through which we can see historical facts. Put another way, Iqbal in this passage is trying to smoothly bring together two methods for treating information from the past. Far from acknowledging a tension in method, he is explicitly invested in positing a shared method. But even here we see cracks starting to form.

So we might see an incoherence between the two kinds of history as starting from differences in content, which we've discussed as a Hegelian position, or as starting from differences in method. We've argued that for Iqbal, the difference in method seems to be primary. Precisely because of the move he makes to make science and religion noncompetitive, Iqbal ends up with a picture that cannot fit the two kinds of history together 
into one single coherent inquiry. While this might seem like a defect in the text, returning to the question of historical-normative reasoning in the next section will bring out some strengths in each historical project. In other words, we understand Iqbal's equivocation over "history" as reflecting a deep philosophical problem about the use of history, rather than a notational inconsistency or a simple mistake.

\section{NORMATIVE CONSEQUENCES}

The three modes of historical-normative reasoning introduced in Section 2 interact with Iqbal's two views about the nature of history in complex ways. Here, we argue that the scientific view of history is only compatible with bidirectional historical analogy. As a result, this conception of history can only in a limited sense be a generative source for original normative insight - mostly, it can be used to make our normative outlooks more consistent. By contrast, history as religious interpretation supports historical genealogy and historical generalization. This would turn history into a powerful source of original moral insight. On this basis, we will offer a partial diagnosis of why Iqbal oscillates between two jointly incoherent conceptions of history. On the one hand, he saw history as a naturalistic form of scientific inquiry - in step with other scientific modes of analyzing the natural world. On the other hand, Iqbal saw history as a foundation for original moral knowledge, and a powerful tool in re-thinking the political position of the Islamic world. He accounts for the former type of historical-normative reasoning by theorizing about history as a science. He tries to explain possibility of the more ambitious kinds of historical-normative reasoning by theorizing about history as interpretation. We are not arguing that these modes of historical-normative reasoning are inherently incompatible. However, we contend that Iqbal's account contains an appeal to two incoherent conceptions of history, perhaps because of the consequences of each type of history for further scientific and political aims. 
On first glance, it might look as if the scientific view of history would fit naturally with historical generalization. After all, many natural sciences involve generalization from observation. But generalization from historic observation to normative propositions works only if the science of history is positioned to extract principles of human nature or society. This ambitious view of the power of historical inference seems intrinsically implausible, but also is at odds with Iqbal's notion of history as science. First of all, generalization presupposes general laws. But Iqbal is explicit that human history is not determined by a conjunction of initial conditions and laws of change. We have already seen that he admires Ibn Khaldūn for recognizing the history is a science of social development in a "creative" and not deterministic manner. He refers to Ibn Khaldūn's conception of historical sciences as "dynamic" and "anti-Classical". ${ }^{54}$ In the Classical conception of history, he contends, social development is "conceived as cyclic" in that the same general rule is instantiated repeatedly. He thus argues that genuine historical sciences, as Ibn Khaldūn conceived of them, are sciences of "eternal creation" and not "eternal repetition." 55

Moreover, Iqbal's account of science as fragmentary also belies the idea that the human nature, in a general way, could be studied by any specific science. Iqbal thinks broad categories such as "life" are not the proper objects of scientific inquiry. ${ }^{56}$ History as a science must draw generalizations in a scientifically rigorous way, and yet to support normative arguments, these generalizations need to be either moral themselves, or directly morally relevant (as opposed to merely satisfying the antecedent of a moral conditional). And so it seems implausible that any scientific history could possibly establish such generalizations to the degree of proof to which we hold generalizations about Biology or Chemistry.

Essentially, the same problem carries over to historical genealogy. Marx, of course, linked scientific history to historical genealogy, in step with the Hegelian tradition. But the 
scope of a Hegelian analysis of historical genealogy is, as we noted before, incredibly ambitious - for Hegel at least, this analysis takes world-history as its necessary subject. For the purposes of this paper, forming a judgment about the validity of this form of historical understanding is not needed. As a category, world history would seem to be closer to life than to cellular mitosis: wider rather than narrower, and reaching into a deep nexus of moral and political connections rather than dealing with the observable and perhaps superficial layer of things. Thus historical genealogy, like historical generalization, requires a wide scope and deep subject-matter whereas historical science, in Iqbal's sense, mandates a narrow scope and empirically verifiable (and hence relatively shallow) subject-matter.

The third method, bidirectional analogy, dispenses with the wide scope of the other two forms. We see no principled reason why history as a science would not support bidirectional historical analogy. One might worry that this form of thinking, weighing specific cases and thinking of possible ways to make the system inconsistent, is not paradigmatic scientific reasoning. However, as Iqbal sees it, science already involves piecemeal reconciliation of experimental data and theoretical posits. And further, nothing he says excludes the possibility of applied moral propositions being part of the subjectmatter of historical inquiry. As we saw, in his notebooks, the science of history is even referred to as "a kind of applied ethics." 57 This kind of reasoning, due to the preceding considerations about scope, will be limited to applied moral propositions, not revision to genuine and original moral principles. In this vein, scientific history can clarify our moral outlook, but would rarely afford new moral knowledge.

Now, on the view of history as religious interpretation, historical-normative reasoning is far less bounded. When we view historical data as a sort of religious text, we are licensed to find great meaning in small details. In analyzing the Qur'ān, we might spend days thinking about a particular line. This close attention is not only rational because the text is deep and 
important, but because it is in the nature of meaning to adhere in the slightest element of a story no less than the climactic scene. A weird observation in a scientific experiment is often an outlier to be put aside, but a strange line in a text is often a window into deep meeting. In part, this may be because we take texts to be intentional, for the most part, and the author's intention leads to small choices no less than large ones. In a scientific inquiry, on the other hand, strange observations are discounted because they are more likely to reflect either mistakes on our parts, or results of the sort of chaotic processes that are almost by their nature inaccessible to us. This comparison oversimplifies both science and interpretation, but we hope the reader will share our intuition that the relation of the part to the whole is essentially different between the two methods.

Interpretation might be genealogical, support generalizations, analogies, or all of these. This is because interpretative methodology depends on the author (or 'author'); to use a somewhat flat-footed analogy, a text is almost like a code, where the author could encode significant information in whichever way they chose, so long as the audience knows how to decode the material. This makes interpretative history potentially morally loaded in every detail. But by the same token, it is now very hard to determine which elements of history might support moral propositions, and which ones. Perhaps for our purposes, it is enough if we can treat history as though it had an author. On some views, that author might be a fictional construct, though it could be God, or the totality of human agency, or any number of things.

A few short steps link treating history as religious interpretation to accepting it as a source of new moral insight. In this sense, an account of history which leaves room for history as interpretation is considerably more generative of moral knowledge than one which limits itself to scientific history. This could explain, at least partially, why Iqbal was tempted by this more ambitious conception of history. Of course, it comes at a cost. Unless 
we can make sense of historical authorship, history as interpretation would certainly have advantages over scientific history - however, one should worry that this reflects the advantage of theft over honest toil.

\section{CONCLUSION}

This paper aimed to bring out a central tension in the Reconstruction: Iqbal talks about history as both a science and as a deep window into religious truths, and yet on his own theory of science, no science could have this close a methodological relationship to religion. These are not superficial commitments of the text - and this conflict, between Iqbal's modest view of science and more expansive view of history, reflects a significant philosophical quandary.

We started this paper with a quote from Sayyid Qutb. Historical-normative reasoning is of course pervasive in many traditions, but it plays a particularly prominent role in Qutb's writing as it does in other Revivalists following Iqbal, including Ali Shariati, Jalal Al-e Ahmad, Fazlur Rahman and Taha Hussein. This reasoning is deeply psychologically compelling as well as philosophically puzzling. How could an enumeration of some things that humans have done possibly ground universal (or at least general) moral knowledge? Looking closely at Iqbal's work suggests an explanation for the prominence of historicalnormative reasoning in the Revivalists, most of whom he influenced in one way or another. The Reconstruction is a bridge between two notions of history, moving from a scientific conception that allows for drawing only case-specific and limited moral conclusions to an interpretive conception that is potentially far more expansive. Perhaps, then, it is this interpretive theory of history that lies beneath the Revivalist reasoning. And since this period also witnessed a creative re-thinking of the process of religious interpretation itself, history as interpretation is a particularly relevant - and loaded- concept. ${ }^{58}$ 


\section{ACKNOWLEDGEMENTS}

We are indebted to Abdul Ansari, Camil Golub, Ali Hadisi, Fereshteh Jamshidi, Meena Krishnamurthy, Kris McDaniels, Arash Naraghi, Peter Railton, Amir Saemi, Jamie Tappendan, and three anonymous reviewers for helpful comments. Thanks also to audiences at Grand Valley State University and the Vancouver Summer Philosophy Conference.

${ }^{1}$ Sayyid Qutb, Milestones: Ma'alim Fi'l-Tareeq, ed. A.B. al-Mehri (Birmingham, England: Maktabah Booksellers and Publishers, 2006), 26-27.

${ }^{2}$ David Hume, A Treatise of Human Nature, ed. David Fate Norton and Mary J. Norton, Oxford Philosophical Texts (Oxford: Oxford Univ. Press, 1739), 302 (3.1.1.27).

${ }^{3}$ We'll use "Islamic Revivalism" to refer to a movement in Islamic thought beginning in the early 20th century and extending until at least the Iranian Revolution, characterized by a common interest in a rebirth of Islamic philosophy oriented toward the colonial and post-colonial context.

${ }^{4}$ See Taha Husayn, "The Future of Culture in Egypt," in The Other Middle East: An Anthology of Modern Levantine Literature, ed. Franck Salameh (Yale University Press, 2018), 289.)

${ }^{5}$ Timur Kuran, "The Genesis of Islamic Economics: A Chapter in the Politics of Muslim Identity," Social Research 64, no. 2 (1997): 321.

${ }^{6}$ Jalal Al Ahmad, Occidentosis: A Plague from the West, ed. Hamid Algar, trans. R. Campbell (Mizan Press, 1984). 
${ }^{7}$ Ali Shariati, Tashayo Alavi va Tashayo Safavi (Alavi Shi'ism and Safavid Shi 'ism, Also Known in English as Red Shi 'ism and Black Shi'ism) (Tehran: Chappakhs, 2017).

${ }^{8}$ Ali Shariati, Marxism and Other Western Fallacies: An Islamic Critique (Mizan Press, 1980).

${ }^{9}$ See $3: 9 ; 3: 137 ; 6: 11 ; 12: 109 ; 16: 36 ; 22: 46 ; 27: 69 ; 29: 20 ; 30: 9 ; 30: 42 ; 35: 44$; $40: 21 ; 40: 82$

${ }^{10}$ For an overview, see Georgios Steiris, "Al-Fārbi on the Role of Philosophy of History in the History of Civilization," in Christian and Islamic Philosophies of Time (Wilmington USA: Vernon Press, 2018), 135-144.

${ }^{11}$ For example, see Averroes, Averroes on Plato's “Republic” (Cornell University Press, 2005), 144-45.

12 Ibn Khaldūn, The Muqaddimah: An Introduction to History, trans. Franz Rosenthal, Princeton Classics (Princeton, NJ: Princeton Univeristy Press, 2015), II.

${ }^{13}$ Muhammad Iqbal, Kuliyat -e- IQBAL (Urdu), 420 (in Bal-e Jibriel [Gabriel's wing]), accessed July 18, 2019, http://archive.org/details/Kuliyat-e-Iqbalurdu. The poem is called 'Masjid-e Qortobeh' (the Cordoba Mosque). Translation by Abdul Ansari (personal correspondence)

${ }^{14}$ Muhammad Iqbal, The Reconstruction of Religious Thought in Islam (Stanford University Press, 2013).

${ }^{15}$ Kuran, "The Genesis of Islamic Economics: A Chapter in the Politics of Muslim Identity."

${ }^{16}$ Barbara Metcalf, “Imagining Muslim Futures: Debates over State and Society at the End of the Raj," Historical Research 80, no. 208 (2007): 286-298; Iqbal Singh Sevea, The Political Philosophy of Muhammad Iqbal: Islam and Nationalism in Late Colonial India (Cambridge ; New York: Cambridge University Press, 2012). 
17 Sayed Khatab, The Power of Sovereignty: The Political and Ideological Philosophy of Sayyid Qutb (Routledge, 2006), 56.

${ }^{18}$ Elisabeth Camp, “Two Varieties of Literary Imagination: Metaphor, Fiction, and Thought Experiments," Midwest Studies in Philosophy 33, no. 1 (2009): 107-130.

${ }^{19}$ However, this need not be the case; Kant, for example, accepts a direction-ofhistory view but is extremely cautious about the prospect of making historical generalization that are empirically verifiable (see Immanuel Kant, "Idea for a Universal History with a Cosmopolitan Purpose," in Kant: Political Writings, trans. H. B. Nisbet, (New York: Cambridge University Press, 1991), 41-53.).

${ }^{20}$ Iqbal, The Reconstruction, 150.

${ }^{21}$ Ibid., 112.

${ }^{22}$ Ibid., 102.

${ }^{23}$ Ibid.

${ }^{24}$ In Iqbal's notes, we read: "I confess I owe a great deal to Hegel, Goethe, Mirza Ghalib, Mirza Abdul, Qadir Bedil and Wordsworth. The first two led me into the ‘inside’ of things [...].” (Muhammad Iqbal, Stray Reflections: Notebooks, ed. Javid Iqbal (Lahore: Sh. Ghulam Ali \& Sons, 1961), 53.). More mysteriously, in a maxim published in the Allahabad-based magazine The New Era (1917), Iqbal admiringly notes: "Hegel's system of philosophy is an epic poem in prose" (Ibid., 25.). For discussion, see Sajjad Rizvi, "Between Hegel and Rumi: Iqbal's Contrapuntal Encounters with the Islamic Philosophical Traditions," in Muhammad Iqbal: Essays on the Reconstruction of Modern Muslim Thought, ed. Chad Hillier and Basit Koshul, (Edinburgh University Press, 2015).

${ }^{25}$ Georg Wilhelm Friedrich Hegel, Introduction to the Philosophy of History, trans. Leo Rauch (Indianapolis \& Cambridge: Hackett Publishing, 1998). 
${ }^{26}$ To be sure, there are alternative readings of Hegel's account of history which deflate his language of "necessity" of the course of history. However, on Iqbal's reading, Hegel does have a rigid conception of the laws of history. This comes through in the Reconstruction, where Iqbal accuse Hegel of conflating a teleological conception of history with fatalism (see Iqbal, The Reconstruction, 88-89.).

27 Fazlur Rahman, Islam and Modernity: Transformation of an Intellectual Tradition, vol. 15 (University of Chicago Press, 1984), 132-33.

${ }^{28}$ Iqbal, The Reconstruction, 33-34.

${ }^{29}$ Ibid., 145.

${ }^{30}$ Ibid., 57.

${ }^{31}$ Ibid., 34.

32 J. S. Haldane et al., “Are Physical, Biological and Psychological Categories Irreducible?," Aristotelian Society Supplementary Volume 1 (1918): 11-74.

${ }^{33}$ Iqbal, The Reconstruction, 34.

${ }^{34}$ Ibid.; emphasis added.

${ }^{35}$ Syed Abdul Vahid, Iqbal: His Art and Thought (John Murray, 1959), 241-42.

${ }^{36}$ Iqbal, The Reconstruction, 113.

${ }^{37}$ Ibid.

${ }^{38}$ Iqbal, Stray Reflections: Notebooks, 31.

${ }^{39}$ Iqbal, The Reconstruction, 99.

${ }^{40}$ Ibid.

${ }^{41}$ Ibid.

${ }^{42}$ Ibid., 99-100.

${ }^{43}$ Ibid., 110. 
44 This approach sometimes takes an extreme form in the Sufi Quranic interpretation [tafsir] tradition. For an interesting example, see Ali Humayun Akhtar, “Identifying Mysticism in Early Esoteric Scriptural Hermeneutics: Sahl al-Tustarı̄’s (d. 283/896) Tafsīr Reconsidered,” Journal of Islamic and Muslim Studies 2, no. 2 (2017): $38-52$.

${ }^{45}$ Iqbal, The Reconstruction, 34.

${ }^{46}$ Ibid.

${ }^{47}$ Iqbal, Kuliyat -e-IQBAL (Urdu), in Ramz-bi-khodi [Secret of Selfessness].

${ }^{48}$ It is something of an Islamic theological orthodoxy that God's names relate to God's attributes. So knowing God's names is related to knowing God's attributes.

${ }^{49}$ Iqbal, The Reconstruction, 110.

${ }^{50} \mathrm{Hegel}$, Introduction to the Philosophy of History, 6-11.

${ }^{51}$ Isaiah Berlin, "The Hedgehog and the Fox: An Essay on Tolstoy's View of History," in Russian Thinkers, ed. Henry Hardy and Aileen Kelly (Penguin Books, 2013), 40 .

${ }^{52}$ Iqbal, The Reconstruction, 34.

${ }^{53}$ Ibid., 111; emphasis added.

${ }^{54}$ Ibid., 102; 112.

${ }^{55}$ Ibid., 111-12.

${ }^{56}$ Ibid., 34-35.

${ }^{57}$ Iqbal, Stray Reflections: Notebooks, 31.

${ }^{58}$ In fact, even self-styled traditionalists from this period such as Abul A'la Maududi were reconfiguring the nature of the interpretation of religious sources, see Sayyid Abul Ala Maududi, "The Meaning of the Qur'ān," Lahore: Islamic 
Publications, 1994; Seyyed Vali Reza Nasr, Mawdudi and the Making of Islamic Revivalism (Oxford University Press, 1996). 